\title{
The effect of heavy metal pollution and presence of Lycopodium annotinum on soil enzyme activity
}

\author{
Anna ŚLIWIŃSKA-WYRZYCHOWSKA ${ }^{1 *}$, Aleksandra NADGÓRSKA-SOCHA ${ }^{2}$ \\ ${ }^{1}$ Department of Botany and Plant Ecology, Institute of Chemistry, Environmental Protection and Biotechnology, \\ Jan Dtugosz University, Armii Krajowej Ave. 13/15, 42-201 Czestochowa, Poland \\ ${ }^{2}$ Department of Ecology, Faculty of Biology and Environment Protection, University of Silesia, \\ Bankowa St. 9, 40-007 Katowice, Poland \\ * Corresponding author. E-mail: a.wyrzychowska@ajd.czest.pl
}

Received June 15, 2010; accepted May 18, 2011; available on-line November 8, 2011

\begin{abstract}
A better understanding of the role of the activity of soil enzymes in the ecosystem will potentially provide a unique opportunity for an integrated biological assessment of soils due to their crucial role in several soil biological activities, their ease of measurement, and their rapid response to changes in soil management practices. 5 study plots with and 5 study plots without occurrence of Lycopodium annotinum, exposed to diverse imission of heavy metals, were chosen for the investigation. The aim of the research was: To estimate the soil pollution by heavy metals; To check the relation between the activity of selected soil enzymes (dehydrogenase, acid and alkaline phosphatases, urease) and heavy metals ( $\mathrm{Zn}, \mathrm{Cd}, \mathrm{Pb})$ in the soil; To estimate the enzyme activity in soils at places of occurrence of Lycopodium annotinum and at places where Lycopodium annotinum does not occur. The soil pollution index after $\mathrm{HNO}_{3}$ and $\mathrm{CaCl}_{2}$ extraction was the highest for the investigated $\dot{Z}$ urada stand. When the metal contents in the acid-extracted fraction and potentially bioavailable fraction of soils from more polluted stands (Chrząstowice, Kolbark, Żurada) were compared to those from cleaner stands (Zrębice, Sokole Góry), higher amounts of metals were found only in the soil of the Żurada stand. For all of the investigated stands the heavy metal contents were lower in the potentially bioavailable fraction than after acid extraction. The highest content among the three analysed elements was found for lead in the acid-extracted fraction. However, a very high (a few hundred times) decrease of the content in the potentially bioavailable fraction $\left(\mathrm{CaCl}_{2}\right.$-extracted) was noticed for this element. We did not observe any reduction of the activity of the investigated enzymes in the soil of the most polluted stand. We did also not observe tendencies to a decrease or increase of the enzyme activity of the soil from the study plots with occurrence of Lycopode, in comparison with the places where Lycopode does not occur. The soil $\mathrm{pH}$ was higher at the places of occurrence of Lycopode.
\end{abstract}

Club moss / Pollution index / Zinc / Lead / Cadmium / Urease / Dehydrogenase / Phosphathase

\section{Introduction}

An important element showing the correct functioning of soil is its biological activity, determined, among others, by the enzymatic activity. In contrast to chemical analyses measuring the content of pollutants, biological parameters reflect environmental consequences that are the result of including pollution in the food chain and especially its influence on the most important processes of soil metabolism [1]. Studies of enzyme activities provide information on biochemical processes occurring in the soil. Enzyme activities are very sensitive to both natural and anthropogenic disturbances, and show a quick response to changes induced in the soil ecosystem [2]. Pollution of soils belongs to the most important ecological problems today. Soil characteristics may be negatively influenced by pollution. Heavy metals in the soil represent a potential risk to the environment [3]. Extreme metal contamination in the vicinity of smelting plants causes clearly visible effects, such as accumulation of organic matter layers on the soil surface through inhibition of the activity of soil microorganisms and soil fauna [4]. A better understanding of the role of the activity of soil enzymes in the ecosystem will potentially provide a unique opportunity for an integrated biological assessment of soils due to their crucial role in several soil biological activities, their ease of measurement, and their rapid response to changes in soil management practices $[3,5,6]$. Rules for diagnosing of forest habitats are mainly determined on the basis of undergrowth, kind of tree stand, quality of the trees in the tree stand; soil is assessed to a lesser extent. 
Microbiological parameters, therein enzymatic activity, are considered to be a good indicator of soil quality, especially for assessing the influence of industrial pollution $[2,7,8]$. Microbiological parameters of soil, including soil enzyme activity, may be effective indicators of environmental, industrial stress and management practices [5]. They have not appeared to be very useful in the diagnosis of forest soils. However, Olszowska et al. [8] showed an essential dependence of the microorganism biomass, intensity of carbon mineralization and enzyme activity on chemical properties of soils. Hence one can use parameters connected with the biological activity of a soil as indicators of its fertility $[8,9,10]$. It seemed of interest to take up studies of the enzymatic activity of soils and the occurrence of the protected species Lycopodium annotinum in stands more or less polluted by heavy metals in fresh pine forest (Leucobryo Pinetum). Differences in the enzymatic activity of soils in direct proximity of Lycopodium roots and from places where Lycopodium does not occur could result from direct or indirect influence of the roots on soils of different levels of pollution. The direct influence of the roots of this species would be connected with releasing enzymes to the soil. The indirect influence would be connected with releasing other metabolites to the soil, which would modify the species composition and microflora activity, thereby the enzymatic activity of the soil. Club mosses are species containing alkaloids that potentially limit the development of pathogenic microorganisms [11]. But there is no data about their influence on soil microflora.

The aim of this research was to estimate the soil pollution by heavy metals and to check the relation between the activity of selected soil enzymes (dehydrogenase, acid and alkaline phosphatases and urease) and heavy metals $(\mathrm{Zn}, \mathrm{Cd}, \mathrm{Pb})$ in the soil. Changes of the soil enzyme activity were considered at places of occurrence of Lycopodium annotinum and in investigation plots from places where Lycopodium annotinum does not occur.

Are the investigated stands characterized by different levels of soil pollution by $\mathrm{Pb}, \mathrm{Cd}, \mathrm{Zn}$ ? Does the heavy metal pollution affect the activity of soil enzymes (dehydrogenase, urease, acid and alkaline phosphatases)? Does the occurrence or absence of Lycopodium annotinum cause a decrease or increase of the activity of the soil enzymes?

\section{Material and methods}

The investigations were performed using soil samples from five different stands. Four of the investigated stands are located in a timber fresh pine coniferous forest (Leucobryo-Pinetum). One (Zrębice) is located in a managed mixed pine-oak forest (Querco roborisPinetum). Three of the analyzed stands (Żurada, Kolbark, Chrzatowice) are located in the southern part of Kraków-Częstochowa Upland. This part of the upland is strongly industrialized and exposed to industrial imission. The investigated stands are located at various distances from Zakłady Górniczo-Hutnicze 'Bolesław' in Bukowno, which emit compounds of sulphur, zinc, lead and cadmium. The two other investigated stands (Sokole Góry, Zrębice) are located in the northern part of Kraków-Częstochowa Upland. This region is relatively unpolluted.

The surface soil samples for the chemical analysis were collected from a layer of $0-10 \mathrm{~cm}$ in May 2009. 10 plots located at the five places exposed to diverse imission by heavy metals were chosen for the study. 5 soil samples of a size up to $10 \mathrm{~m}^{2}$ were taken from each Lycopodium annotinum site. The places of sample collection were situated evenly over the area occupied by club moss. There were five plots with and five plots without occurrence of Lycopodium annotinum. The heavy metal content was estimated according to the methods of Bouwman et al. [12], and Ostrowska et al. [13], in air-dried soil samples, which were sieved through a $1 \mathrm{~mm}$ sieve. The heavy metals were extracted using $0.01 \mathrm{M} \quad \mathrm{CaCl}_{2}$ (potentially bioavailable fraction) or $10 \% \mathrm{HNO}_{3}$ (acid-extracted fraction). The metal contents were measured in the filtered extracts. The analyses were performed using a graphite furnace atomic absorption spectrophotometer (AAS UNICAM 939 Solar). The soil $\mathrm{pH}$ was measured in water (1:2.5 soil:water ratio) using a $\mathrm{pH}$ meter [13]. The organic matter content, expressed in $\%$, was estimated using the gravimetric method from the mass loss during sample roasting in a muffle furnace at $550{ }^{\circ} \mathrm{C}$ [13]. The soil pollution index (SPI) was calculated for each locality according to the equation given below [14,15] and was based on limit values as reported in [16]. The limit values (permissible concentration) of heavy metal contents in soils were: $\mathrm{Zn}-\quad 300 \mathrm{mg} \mathrm{kg}^{-1}$ d.m., $\quad \mathrm{Pb}-$ $100 \mathrm{mg} \mathrm{kg}^{-1}$ d.m., $\mathrm{Cd}-4 \mathrm{mg} \mathrm{kg}^{-1}$ d.m.

$S P I=\frac{1}{n} \cdot \sum_{i=1}^{n} \cdot 100 \cdot \frac{V S_{i}}{L S}$

$n$ - number of elements,

$V S$ - content of an element in the soil, in $\mathrm{mg} \mathrm{kg}^{-1} \mathrm{~d} . \mathrm{m}$., $L S$ - limit value for an element in the soil, in $\mathrm{mg} \mathrm{kg}{ }^{-1}$ d.m.

The enzymatic investigations included changes of nitrogen compounds (urease activity), release of inorganic phosphates (acid and alkaline phosphatases) and organic matter (dehydrogenase activity). The activity of the soil enzymes was determined in soil samples at field moisture, sieved through a $2 \mathrm{~mm}$ sieve. The activity of alkaline and acid phosphatase was measured according to the method of Schinner et al. [17]. The p-nitrophenol (NP) released by the phosphomonoesterase activity was extracted, coloured with sodium hydroxide and determined photometrically at $400 \mathrm{~nm}$. The activity of the phosphatases was expressed in $\mu \mathrm{g}$ p-nitrophenol (NP) $\mathrm{g}^{-1}$ d.m. or dry matter $\mathrm{h}^{-1}$. 
Table 1 Soil pollution index, soil organic matter content and $\mathrm{pH}$ value of surface soil samples from different areas. Different letters indicate statistically significant differences between the data for soil organic matter contents and $\mathrm{pH}$ values.

\begin{tabular}{l|c|c|c|c}
\hline $\begin{array}{l}\text { Investigated } \\
\text { stand }\end{array}$ & $\begin{array}{c}\text { Pollution index for } \\
\text { soil after } \mathrm{HNO}_{3} \\
\text { extraction }\end{array}$ & $\begin{array}{c}\text { Pollution index for } \\
\text { soil after } \mathrm{CaCl}_{2} \\
\text { extraction }\end{array}$ & $\begin{array}{c}\text { Soil organic matter } \\
\text { content [\%] }\end{array}$ & $\begin{array}{c}\text { pH value for } \\
\text { surface soil } \\
\text { samples }\end{array}$ \\
\hline Żurada & 236.3 & 14.9 & $25.3 \pm 1.1 \mathrm{a}$ & $6.79 \pm 0.02 \mathrm{a}$ \\
Kolbark & 183.8 & 7.9 & $14.5 \pm 0.2 \mathrm{~b}$ & $6.65 \pm 0.01 \mathrm{~b}$ \\
Chrząstowice & 145.1 & 8.7 & $16.8 \pm 0.8 \mathrm{c}$ & $6.24 \pm 0.02 \mathrm{c}$ \\
Zrębice & 84.6 & 5.7 & $22.6 \pm 0.5 \mathrm{~d}$ & $6.7 \pm 0.02 \mathrm{~d}$ \\
Sokole Góry & 149.2 & 6.6 & $16.1 \pm 0.1 \mathrm{e}$ & $6.49 \pm 0.01 \mathrm{e}$ \\
\hline
\end{tabular}

Table 2 Average heavy metal concentrations $\left[\mathrm{mg} \mathrm{kg}^{-1} \mathrm{~d} . \mathrm{m}.\right]$ in surface soil samples of the investigated stands. Different letters denote significant differences between the data for each examined metal concentration $(p<0.05)$.

\begin{tabular}{|c|c|c|c|c|c|c|c|}
\hline Element & \multicolumn{2}{|c|}{$\mathrm{Zn}$} & \multicolumn{3}{|c|}{$\mathrm{Pb}$} & \multicolumn{2}{|c|}{$\mathrm{Cd}$} \\
\hline $\begin{array}{l}\text { Investigated } \\
\text { stand }\end{array}$ & $\begin{array}{l}\mathrm{HNO}_{3^{-}} \\
\text {extracted }\end{array}$ & $\begin{array}{l}\mathrm{CaCl}_{2-}^{-} \\
\text {extracted }\end{array}$ & $\begin{array}{l}\mathrm{HNO}_{3^{-}} \\
\text {extracted }\end{array}$ & & $\begin{array}{l}\mathrm{CaCl}_{2^{-}} \\
\text {extracted }\end{array}$ & $\begin{array}{l}\mathrm{HNO}_{3-}^{-} \\
\text {extracted }\end{array}$ & $\begin{array}{l}\mathrm{CaCl}_{2-}^{-} \\
\text {extracted }\end{array}$ \\
\hline Żurada & $84.20 \pm 9.80$ & $43.97 \pm 0.90 \quad \mathrm{a}$ & $1096.0 \pm 5.6$ & $\mathrm{a}$ & $5.50 \pm 0.10 \mathrm{a}$ & $3.30 \pm 0.20 \mathrm{a}$ & $0.99 \pm 0.15 \mathrm{a}$ \\
\hline Kolbark & $28.52 \pm 0.20$ & $18.40 \pm 0.60$ & $499.7 \pm 8.8$ & $\mathrm{~b}$ & $2.40 \pm 0.14 \mathrm{~b}$ & $1.46 \pm 0.07 \mathrm{~b}$ & $0.56 \pm 0.05 \mathrm{~b}$ \\
\hline Chrząstowice & $47.20 \pm 2.90$ & $25.90 \pm 0.80$ & $400.0 \pm 21.6$ & $\mathrm{c}$ & $2.60 \pm 0.29 b$ & $1.43 \pm 0.22 b$ & $0.59 \pm 0.03 \mathrm{~b}$ \\
\hline Zrębice & $48.90 \pm 0.13$ & $18.80 \pm 0.24$ & $201.6 \pm 4.9$ & d & $0.50 \pm 0.10 \mathrm{c}$ & $1.27 \pm 0.09 \mathrm{~b}$ & $0.42 \pm 0.04 \mathrm{~b}$ \\
\hline Sokole Góry & $28.80 \pm 0.90$ & $14.42 \pm 0.60$ & $794.0 \pm 7.0$ & c & $3.35 \pm 0.13 \mathrm{~d}$ & $1.35 \pm 0.16 \mathrm{~b}$ & $0.47 \pm 0.04 \mathrm{~b}$ \\
\hline
\end{tabular}

The estimation of urease activity was based on the colorimetric determination of the formation of ammonium after enzymatic urea hydrolysis $(10 \%$ solution, $\lambda=630 \mathrm{~nm}$ ). The urease activity was expressed in $\mu \mathrm{g} \mathrm{NH} \mathrm{g}^{-1}$ d.m. [17]. Triphenyltetrazolium chloride was used as substrate for the determination of the dehydrogenase activity. The triphenyl formazan (TPF) produced was extracted with acetone and measured photometrically at $546 \mathrm{~nm}$. The dehydrogenase activity was expressed in $\mu \mathrm{g}$ triphenyl formazan (TPF) $\mathrm{g}^{-1}$ d.m. $16 \mathrm{~h}^{-1}$ [17]. The results are presented as mean values from three replicates of each treatment, together with the standard deviation (SD) from the means. The data was analysed using the software Statistica to compute significant statistical differences (significance level $p<0.05$ ) between samples according to Tukey's multiple range test and to compute Pearson's correlation coefficients.

\section{Results and discussion}

Heavy metals are inhibitors of the enzymatic activity in soils. Longstanding accumulation of heavy metals, especially in surface soil, causes changes of the enzyme activity and can lead to reduced decomposition of organic substance [1,4]. This statement can be demonstrated by calculating the pollution index for different places (study areas). Five places exposed to diverse imission by heavy metals were chosen for the study. The pollution index was the highest for the most polluted site (Table 1).

When the presence of metals: $\mathrm{Zn}, \mathrm{Pb}$ and $\mathrm{Cd}$ in the acid-extracted fraction and potentially bioavailable fraction of the soil from the more polluted areas (Chrzastowice, Kolbark) was compared to those from the cleaner areas (Zrębice, Sokole Góry), higher amounts of metals were found only in the soil of the Żurada stand (Table 2). The Żurada stand was located at the shortest distance from the heavy metal emitter Zakłady Górniczo-Hutnicze 'Bolesław' in Bukowno. For all the investigated areas the highest metal concentrations were found for $\mathrm{Pb}$ (after $10 \% \mathrm{HNO}_{3}$ extraction). The concentrations ranged from $201.6 \mathrm{mg} \mathrm{kg}^{-1}$ d.m. in the Zrębice stand to $1096 \mathrm{mg} \mathrm{kg}^{-1}$ d.m. (Żurada). The $\mathrm{Pb}$ concentrations were above the value considered as permissible [16]. The $\mathrm{Zn}$ contents varied from $28.5 \mathrm{mg} \mathrm{kg}^{-1}$ d.m. (Kolbark) to $84.2 \mathrm{mg} \mathrm{kg}^{-1}$ d.m. (Żurada). The highest $\mathrm{Cd}$ concentration in the surface soil sample after acid extraction was observed for the Żurada stand (3.3 $\mathrm{mg} \mathrm{kg}^{-1}$ d.m.). Similar amounts were found in the other areas. The $\mathrm{Zn}$ and $\mathrm{Cd}$ concentrations (after acid extraction) and the amounts of all the investigated metals in the potentially bioavailable fraction (after $\mathrm{CaCl}_{2}$ extraction) were below the concentrations considered as permissible. For all the investigated areas the $\mathrm{Pb}$ contents in the bioavailable fraction were lower than the $\mathrm{Pb}$ amounts obtained after acid extraction (Table 2).

The methods used for the evaluation of the pool of soluble (potentially bioavailable) trace elements in soils were based mainly on extractions with various solutions of mineral acids at various concentrations, chelating agents, e.g. EDTA; buffering salts, e.g. $\mathrm{NH}_{4} \mathrm{OAc}$, neutral salts, e.g. $\mathrm{CaCl}_{2}, \mathrm{MgCl}_{2}, \mathrm{NH}_{4} \mathrm{NO}_{3}$, and other extractants. The heavy metal 


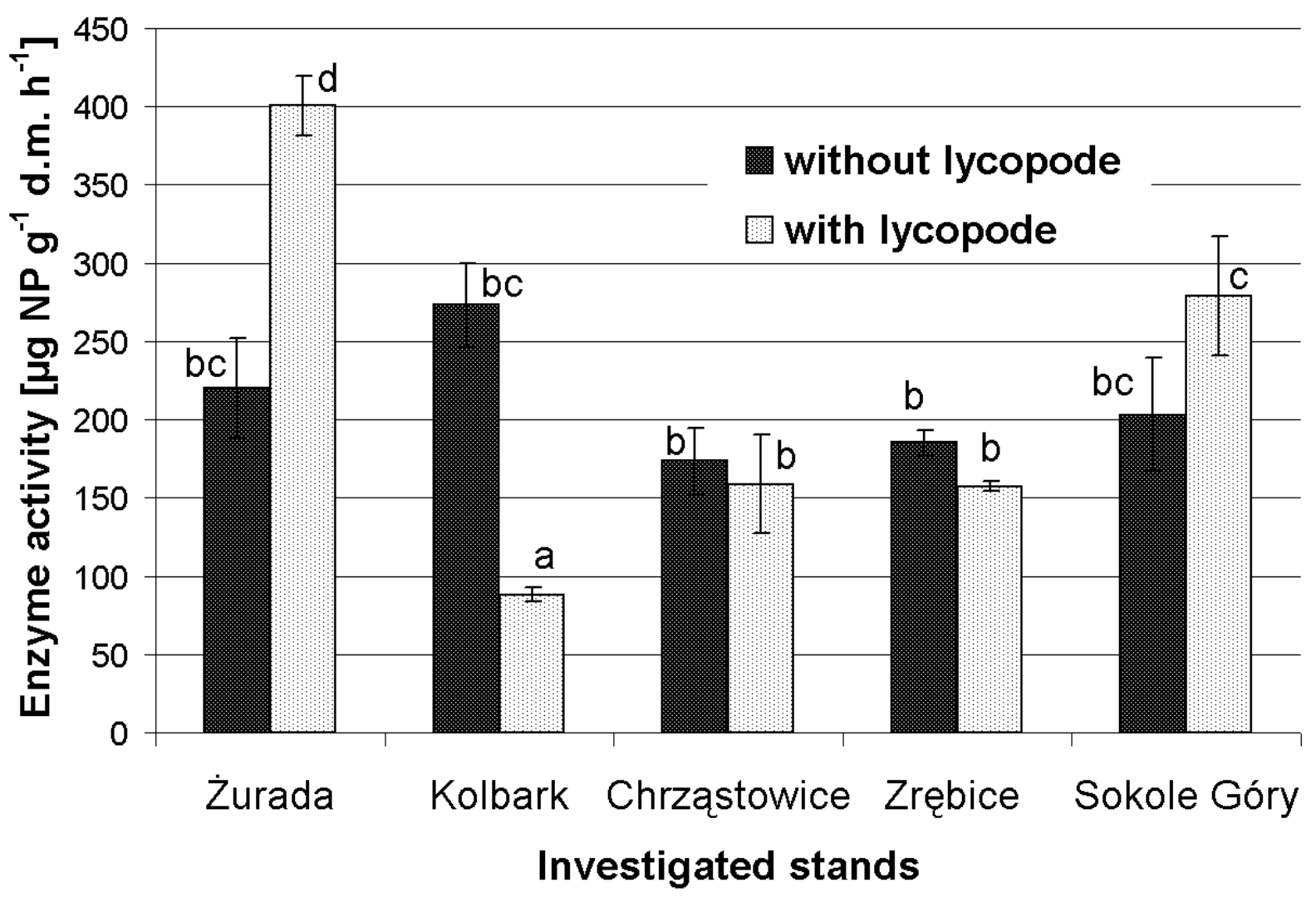

Fig. 1 Average acid phosphatase activity in surface soil samples of the investigated study plots with standard deviation. The different letters denote significant differences between the data for each examined enzyme activity $(p<0.05)$.

concentrations were lower (or in the same range for $\mathrm{Pb}$ ) than the contents observed in the vicinity of the Szopienice plant and in surface soil samples of heaps in the vicinity of Piekary Ślaskie and Bytom - the most polluted area of the Silesia region $[18,19]$.

In a previous study of samples taken in the vicinity of the smelting plant Zakłady Górniczo-Hutnicze Bolesław in Bukowno a similar amount of $\mathrm{Pb}-$ $1025 \mathrm{mg} \mathrm{kg}^{-1}$ d.m. was obtained [20]. In the study by Kucharski and Marchwicka the $\mathrm{Pb}$ content in the Bukowno region was $46-1520 \mathrm{~g} \mathrm{~kg}^{-1}$ d.m., $\mathrm{Zn}$ 90-920 $\mathrm{g} \mathrm{kg}^{-1} \mathrm{~d}$.m. and $\mathrm{Cd} 1-42 \mathrm{~g} \mathrm{~kg}^{-1}$ d.m. [21]. The high $\mathrm{Pb}$ concentration in the soil is typical for the surroundings of industrial plants that handle ore or scrap containing this element and dump industrial waste. From 1011 to $1280 \mathrm{mg} \mathrm{Pb}$ per $\mathrm{kg}$ soil was observed in the near vicinity of the non-ferrous plant Szopienice, and $1631 \mathrm{mg} \mathrm{Pb}$ per $\mathrm{kg}$ of soil in the heap located on the north part of the Waryński plant in the district of Piekary Śląskie Brzozowice [22,23].

The contents of $\mathrm{Pb}$ and $\mathrm{Cd}$ in the most polluted stand - Żurada - were of the same magnitude as those obtained by Olszowska et al. [8] ( $\mathrm{Zn}-$ $437 \mathrm{mg} \mathrm{kg}^{-1}$ d.m., $\quad \mathrm{Pb}-1002 \mathrm{mg} \mathrm{kg}^{-1}$ d.m., $\quad \mathrm{Cd}-$ $3.90 \mathrm{mg} \mathrm{kg}^{-1}$ d.m.) in a pine coniferous forest of age class III in the threat zone III in the region of the activity of the smelter "Miasteczko Śląskie". In this investigation concentrated acids $\left(\mathrm{HNO}_{3}: \mathrm{HClO}_{4} ; 4: 1\right)$ were used for the soil extraction.

A relatively high content of organic substance (13.2-28.8\%) was detected and low $\mathrm{pH}$ values were found for the surface soil, typical for fresh pine forest. Ostrowska et al. reported contents of organic substance in surface forest soils ranging from 12 to $35 \%$ [13].

Concerning the enzyme activity we found the following tendencies: The acid phosphatase activity (Fig. 1) was higher than its alkaline counterpart (Fig. 2). The $\mathrm{pH}$ value (Table 1) had significant effect on the obtained results. The activity of acid phosphatase in soil was similar for the most and less polluted study plots and no decrease was detected for the most polluted plot. The activity was in general lower or of similar magnitude (except for Żurada and Sokole Góry) at the places where Lycopodium occurred (Fig. 1). The highest dehydrogenase activity was observed in the Zrębice study plot without lycopode (Fig. 3). No reduction of the activity of this enzyme was observed for the most polluted stand (Żurada). The highest urease activity was found in the Zrębice study plot where Lycopodium did not occur and in the Kolbark study plot where it occurred (Fig. 4). Higher or comparable urease activity was observed for the places where lycopode was 


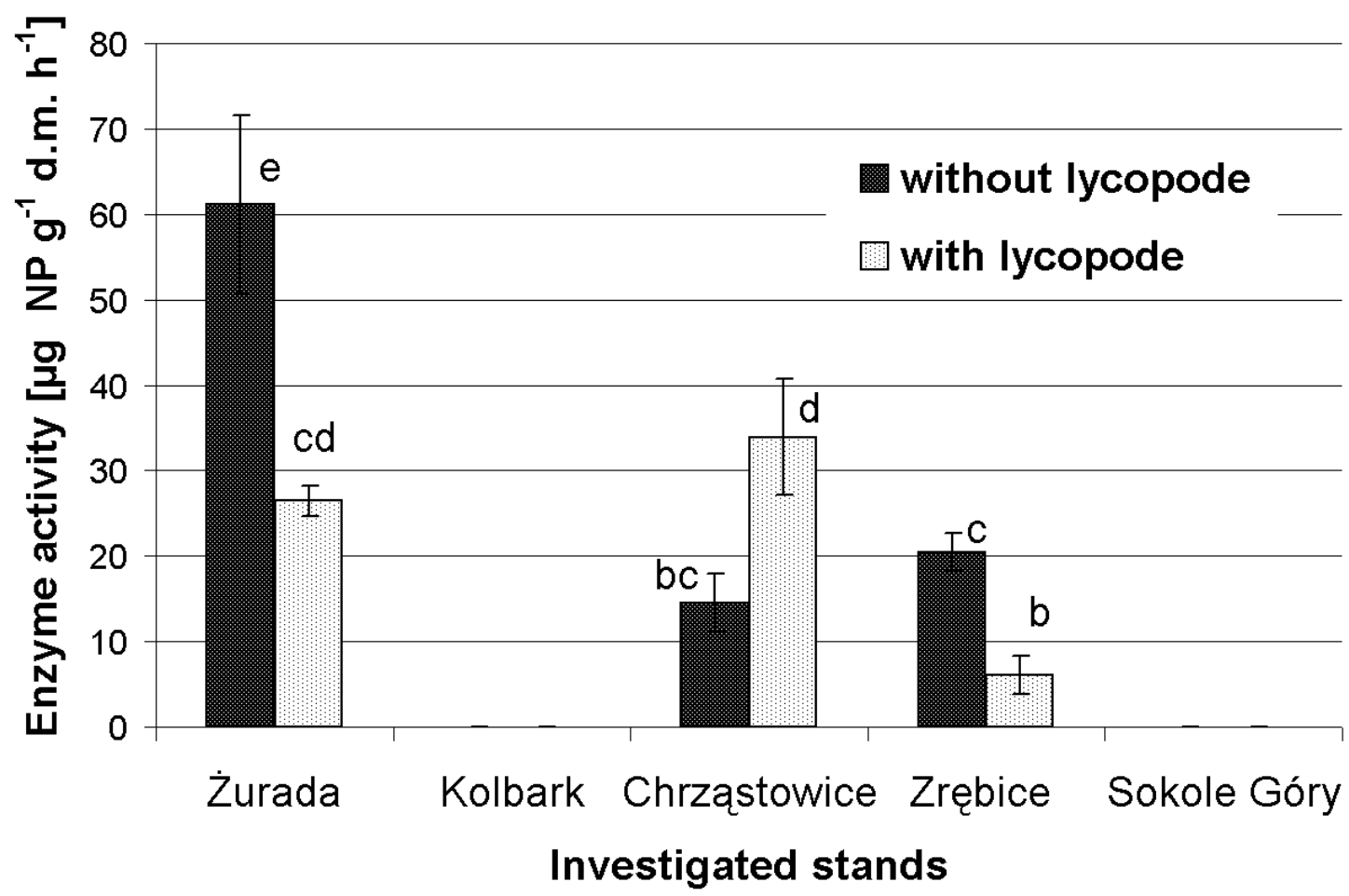

Fig. 2 Average alkaline phosphatase activity in surface soil samples of the investigated study plots with standard deviation. The different letters denote significant differences between the data for each examined enzyme activity $(p<0.05)$.

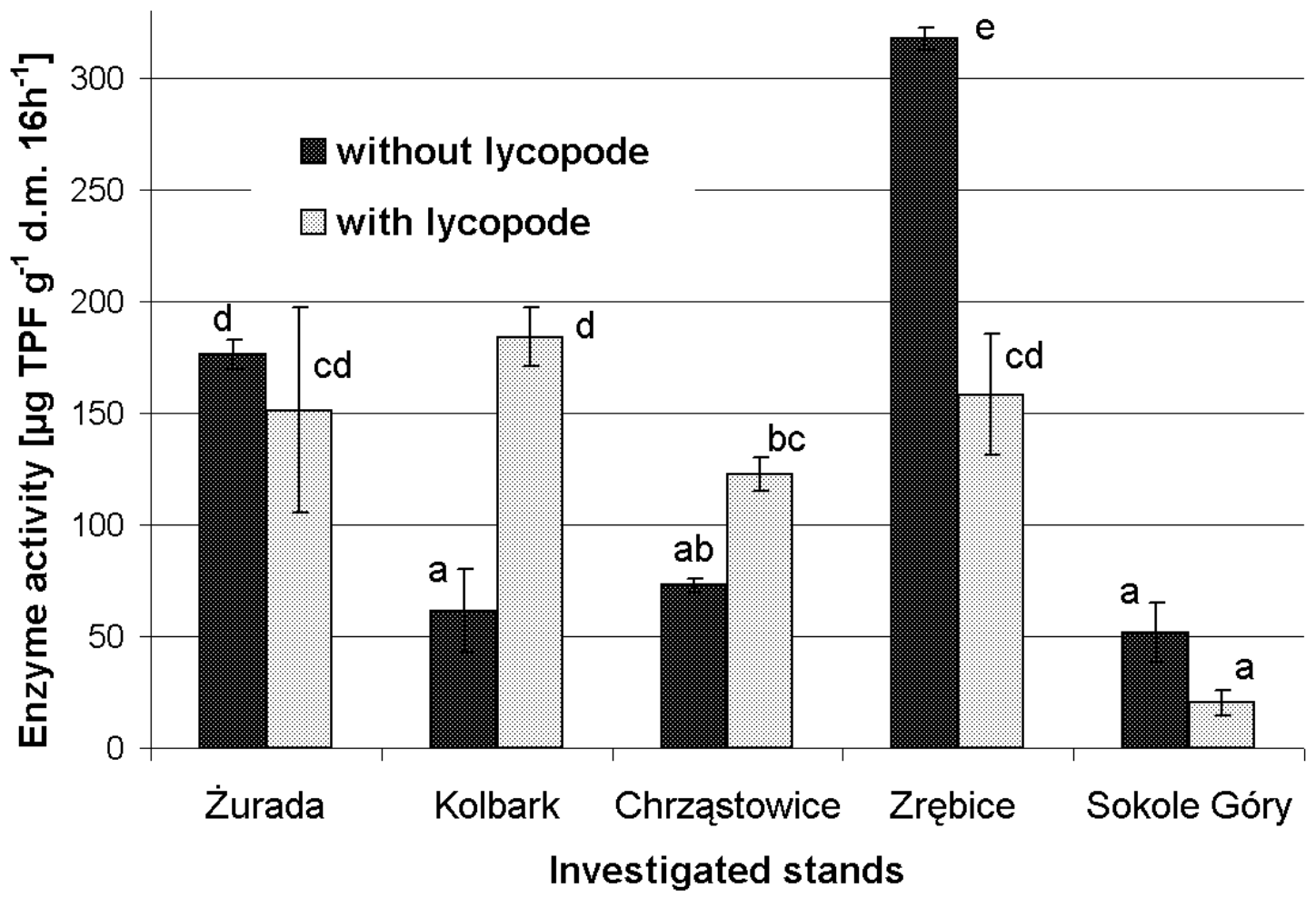

Fig. 3 Average dehydrogenase activity in surface soil samples of the investigated study plots with standard deviation. The different letters denote significant differences between the data for each examined enzyme activity $(p<0.05)$. 


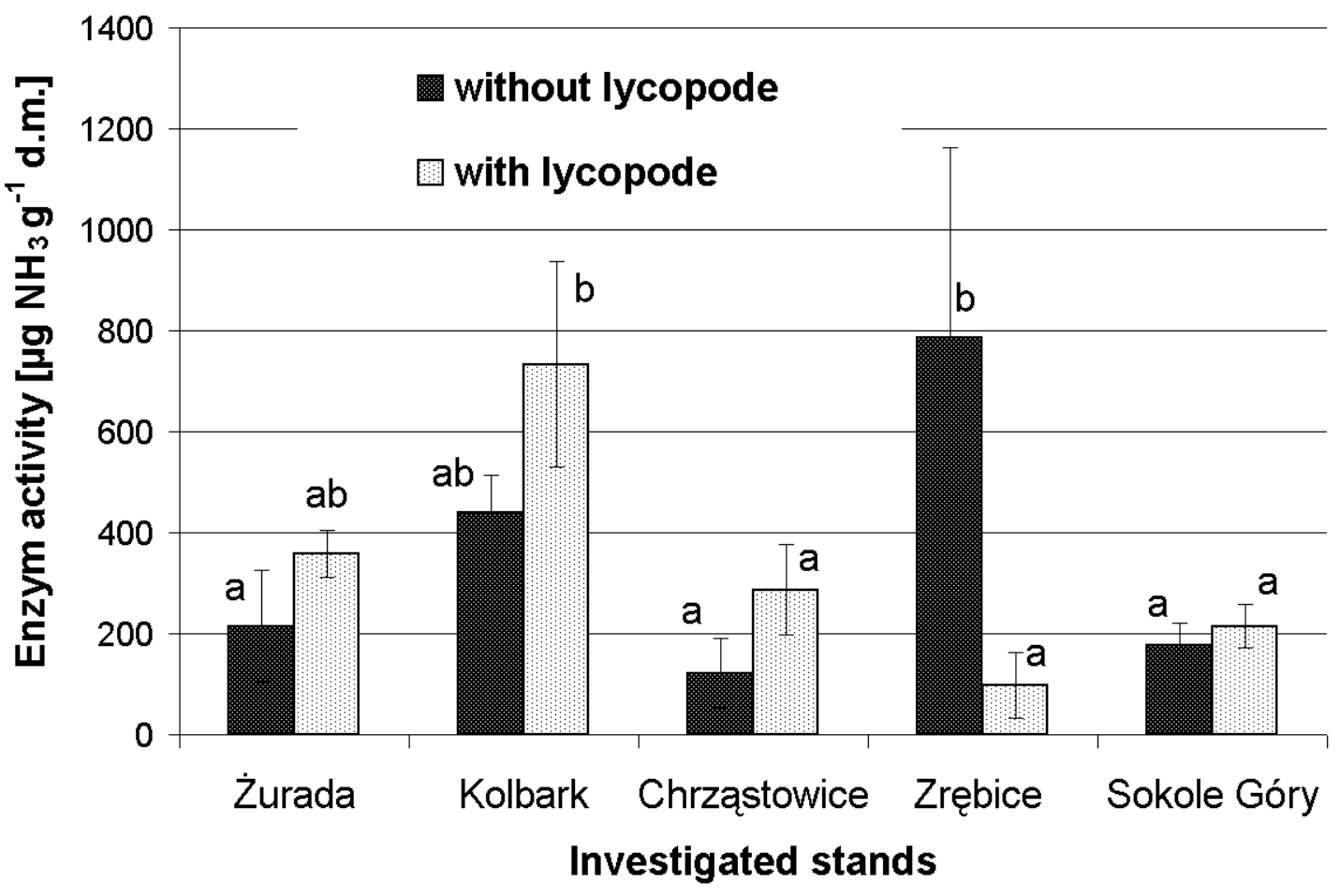

Fig. 4 Average urease activity in surface soil samples of the investigated study plots with standard deviation. The different letters denote significant differences between the data for each examined enzyme activity $(p<0.05)$.

found for most of the investigated study plots (except for Zrębice). The enzyme activity in surface soil in the study plots was connected with a relatively high content of organic substance. The main source of enzymes in soil environment is soil microorganisms, but also plant roots and soil fauna contribute. Acid phosphatase dominates in acid soils with a small addition of alkaline phosphatase and this situation is representative of fresh pine forests in the present study (the alkaline phosphatase activities were lower than the acid counterpart and in Kolbark and Sokole Góry no alkaline phosphatase activity was detected).

The activity of phosphatases in soil environment reflects enzyme activity connected with soil colloids and humus substances, free phosphatases in soil solution and phosphatases tied with live and dead cells of plants and microorganisms. Phosphatases can be a good indicator of the organic phosphor mineralization potential and biological activity of soils. Bielińska $[24,25,26]$, basing herself on long studies of the activity of selected soil enzymes (dehydrogenases, phosphatases, urease, protease), concluded that the closest connections with physical and chemical soil properties were observed for phosphatases and the weakest for dehydrogenases. The results obtained by Ciarciowska and Gambuś [1] do also not show any close correlation between the content of heavy metals and the level of dehydrogenase activity. In the soils of "old heaps" in the vicinity of Olkusz, despite strong pollution the high level of dehydrogenase activity could be the result of the high content of organic substance and neutral reactions, which, in the first case, would confirm the results obtained in the present study. A high content of organic substance can be changed into biologically inactive forms [1]. We obtained statistically significant correlation coefficients for the activity of alkaline phosphatase (0.87), acid phosphatase (0.63), dehydrogenase (0.77) and for the content of soil organic matter. These results were confirmed by the low bioavailability of Pb. Wyszkowska and Wyszkowski [10] underlined that significant weakening of the biological life of soil can be the result not only of the total content of heavy metals in the soil (in the present study after extraction with $\left.10 \% \quad \mathrm{HNO}_{3}\right)$ or of the concentration of bioavailable forms, but it can also be the result of many other factors. The activity of the soil enzymes considered in the present study is comparable with their activity in surface soil of pine forests in the vicinity of the "Miasteczko Śląskie" smelter in zones of lower threat (I-III), reported in studies by Olszowska et al. [8], and in soils of Scots pine forests in the forestry management Włoszczowa and Opoczno in different classes of tree stand bonitation [27].

The enzyme activity of soil depends on physical and chemical characteristics of the soil and pollutants 
such as heavy metals. These factors cause various degrees of change in the enzyme activities [3]. On the other hand, the content of organic substance or the soil $\mathrm{pH}$ can have a significant influence on the decrease of available forms of heavy metals and their biological inactivation, and the expected reduction of activity is often not observed. The influence of the presence, or absence, of Lycopodium on the enzymatic activity of soil requires further detailed studies. Enzymatic activities can sensitively reflect the biological situation in the soil $[27,28]$. The main reasons why enzymatic activities may be good indicators of soil quality are: 1) they change earlier than other characteristics; 2) their analysis involves relatively simple methods compared to other important parameters of soil quality [2]. Studies of the enzymatic activity of soils seem to be an essential complement to studies of the chemical properties of forest habitats, as highlighted by Olszowska et al. in their studies [27,29].

\section{Conclusion}

The studied stands are characterized by diverse levels of soil pollution. The most polluted stand is located close to a heavy metal emitter. No significant influence of the heavy metals on the activity of the studied enzymes in the surface soil was observed in the study, but the problem requires further studies. No reduction of the enzymatic activity of the soil was detected for the most polluted stand (Żurada). This could be connected with the high content of organic matter and the low bioavailability of the studied elements.

We did not observe any decrease or increase of the enzymatic activity of the soil for the study plots with occurrence of Lycopodium annotinu, in comparison with the places where Lycopode did not occur. For of all of the investigated areas the soil $\mathrm{pH}$ values were higher at the places of occurrence of L. annotinum.

\section{References}

[1] K. Ciarkowska., F. Gambuś, Zesz. Probl. Postepow Nauk Roln. 501 (2004) 79-85.

[2] C.E. Pankhurst, B.E. Double, V.V.S.R. Gupta (Eds.) Biological Indicators of Soil Health, CAB International, New York, 1997, pp. 121-151.

[3] O. Micanová, J. Geochem. Explor. 88 (2006) 220-223.

[4] G. Tyler, Effect of Heavy Metal Pollution on the Decomposition and Mineralisation Rates in Forest Soils, In: A. Hutchinson, L. Page, J. Loon (Eds.), Heavy Metals in the Environment, Toronto, 1975, pp. 217-226.

[5] R. Kizilkaya, T. Aşkin, Agriculturae Conspectus Scientificus 72(1) (2007) 89-94.
[6] J.H.J.R. Makoi, P.A. Ndakidemi, Afr. J. Biotechnol. 7(3) (2008) 181-191.

[7] J. Wyszkowska, J. Kucharski, E. Wałdowska, Rostl. Vyroba 48(2) (2002) 58-62.

[8] G. Olszowska, J. Zwoliński, I. Matuszczyk, D. Syrek, Forest Res. Pap. (4) (2007) 83-105.

[9] J. Kucharski, A. Hłasko, J. Wyszkowska, Zesz. Probl. Postepow Nauk Roln. 476 (2001) 173-180 (in Polish).

[10] J. Wyszkowska, M. Wyszkowski, Pol. J. Environ. Stud. 11(5) (2002) 585-591.

[11] I. Orhan, B. Özcelik, S. Aslan, M. Kartal, T. Karaoglu, B. Şener, S. Terzioglu, M. Iqbal Choudhary, Phytochem. Rev. 6 (2007) 189-196.

[12] L. Bouwman, J. Bloem, P. Römkens, G. Boon, J. Vangronsveld, Minerva Biotechnol. 13 (2001) 19-26.

[13] A. Ostrowska, S. Gawliński, Z. Szczubiałka, Methods of Analysis and Assessment of Soil and Plant Properties, Catalogue, Instytut Ochrony Środowiska, Warsaw, 1991, pp. 334-340 (in Polish).

[14] M. Sanka, M. Strnad, J. Vondra, E. Paterson, Int. J. Environ. Anal. Chem. 59 (1995) 327-343.

[15] J. Diatta, W. Grzebisz, K. Apolinarska, Electron. J. Pol. Agric. Univ. 6(2) (2003) \#01. http://www.ejpau.media.pl/volume6/issue2/envir onment/art-01.html

[16] The regulation of Environment Minister about the standards of soil and ground quality, The Act Gazette of Poland nr 165 pos. 1358 i 1359 from 9.09.2002.

[17] F. Schinner, R. Öhlinger, E. Kandeler, R. Margensin (Eds.), Methods in Soil Biology, Springer-Verlag, Berlin-Heidelberg, 1995, pp. 171-174, 213-216, 241-243.

[18] M. Heflik, A. Nadgórska-Socha, R. Ciepał, Ecol. Chem. Eng. 13(7) (2006) 657-663.

[19] A. Nadgórska-Socha, I. Łukasik, R. Ciepał, S. Pomierny, Acta Agrophysica 8(3) (2006) 713-725.

[20] B. Palowski, T. Kimsa, E. Sierka, R. Ciepał, I. Łukasik, Acta Agrophysica 51 (2001) 143-150.

[21] R. Kucharski, E. Marchwicka, Zesz. Nauk. Akad. Górn.-Hutn. im Stanislawa Staszica, Chem. 1368(32) (1990) 123-141 (in Polish).

[22] A. Nadgórska-Socha, R. Ciepał, Ecol. Chem. Eng. A 16(7) (2009) 831-837).

[23] G. Olszowska, Work of the Research Institute of Forestry, Serie A 834, Warsaw, 1997, pp. 107129 (in Polish).

[24] E. Bielińska, Zesz. Probl. Postepow Nauk Roln. 505 (2005) 51-58 (in Polish).

[25] E. Bielińska, J. Res. Appl. Agric. Eng. 47(1) (2002) 38-44 (in Polish).

[26] E. Bielińska, A. Mocek-Płóciniak, Phosphatases in Soil Environment, Wydawnictwo Uniwersytetu Przyrodniczego w Poznaniu, Poznań, 2009, pp. 1-41 (in Polish). 
A. Śliwińska-Wyrzychowska, A. Nadgórska-Socha, The effect of heavy metal pollution ...

[27] G. Olszowska, J. Zwoliński, I. Matuszczyk, D. Syrek, B. Zwolińska, U. Pawlak, Z. Kwapis, M. Dudzińska, Forest Res. Pap. (3) (2005) 17-37 (in Polish).
[28] M. Smejkalova, O. Mikanova, L. Boruvka, Plant Soil Environ. 49(7) (2003) 321-326.

[29] G. Olszowska, Forest Res. Pap. 70(4) (2009) 383-394 (in Polish).

Proceeding of the XVI International Seminar on Physics and Chemistry of Solids, Lviv, June 6-9, 2010. 